\title{
The Role of Skills in Understanding Low Income in Canada
}

Andrew Heisz, Statistics Canada

Geranda Notten, University of Ottawa

Jerry Situ, Statistics Canada

doi:10.1108/S1049-258520150000023005

To cite this document:

Andrew Heisz Geranda Notten Jerry Situ . "The Role of Skills in Understanding Low Income in Canada" In Measurement of Poverty, Deprivation, and Economic Mobility. Published online: 26 Aug 2015; 153-184.

\begin{abstract}
This research explores how skill proficiencies are distributed between low-income and not-in lowincome groups using the results of a highly complex survey of the information-processing skills of Canadians between the ages of 16 and 65 . We find that having measures of skills enhances our understanding of the correlates of low income. Skills have an independent effect, even when controlling for other known correlates of low income, and their inclusion reduces the independent effect of education and immigrant status. This result is relevant for public policy development as the knowledge of the skills profile of the low-income population can inform the design of efficient and effective programmes.
\end{abstract}

Keywords: Poverty; low income; skills; PIAAC; LISA; Canada

JEL classifications: D31; 124; 132; 138 
'This article is (C) Emerald Group Publishing and permission has been granted for this version to appear here http://dx.doi.org/10.1108/S1049-258520150000023005. Emerald does not grant permission for this article to be further copied/distributed or hosted elsewhere without the express permission from Emerald Group Publishing Limited.'

\section{Introduction}

Understanding the composition of the low-income population in Canada as been the subject of numerous studies. ${ }^{1}$ Characteristics such as immigrant status, disability, low education and lone parenthood have each been found to be concentrated among the low-income population, and these findings have informed policy development in Canada. A factor that has received less attention is skill level, by which we mean fundamental literacy, numeracy and problem-solving skills. It is likely that these skills are an important correlate of low income, and furthermore, it is possible that previously studied correlates of low income, such as low education or immigrant status, are, in-part, proxies for skills. However, due to lack of direct skill measurements on surveys that also measure income, it is not known how important low skills are to understanding low income.

This research uses the first wave of the new Canadian Longitudinal and International Study of Adults (LISA) to explore the relationship between literacy, numeracy and problem-solving skills, which we refer to as 'information-processing skills', and household income. This dataset is unique because it holds highquality information on household income, information-processing skills and a full set of other correlates usually found to be important in determining household income levels. In LISA, estimates of skills are obtained through direct measures of respondents' literacy, numeracy and problem-solving skills using international scales developed for the Program for International Assessment of Adult Competencies (PIAAC). We explore how skill levels are distributed between low income and non-low-income groups and ask whether the low-income population has lower skill proficiency levels and whether these remain after controlling for other characteristics known to increase the risk of low income for Canadians. This differentiates our study from those that seek to explain the causal effect of literacy on labour market earnings such as Green and Riddell (2007) and Osberg (2000).

The research uncovers an important relationship between low income and low skills that persists after controlling for other respondent and family characteristics. For example, after controlling for respondent education level, immigrant status, activity limitation, family structure and age group, respondents with a low proficiency in literacy had a low-income rate about 12 percentage points higher than respondents with a high proficiency in literacy. This result is relevant for public policy development as the skills profile of the low-income population could inform the design of efficient and effective

\footnotetext{
${ }^{1}$ Canada does not have an official definition of poverty. Low-income rates, such as those used in this study, are often used as proxies for poverty rates. In this study, we use the terms poverty and low income interchangeably.
} 
'This article is (C) Emerald Group Publishing and permission has been granted for this version to appear here http://dx.doi.org/10.1108/S1049-258520150000023005. Emerald does not grant permission for this article to be further copied/distributed or hosted elsewhere without the express permission from Emerald Group Publishing Limited.'

programmes (Hamilton \& Torraco, 2013). First, it emphasises the likely importance of fundamental skills as an individual determinant of economic wellbeing. Second, the availability of measures of fundamental skills such as those used in this study can help settle longstanding debates on the costeffectiveness of policy measures aimed at either increasing general or specific skills among population groups such as welfare recipients, displaced workers or low-skilled workers (Gyarmati et al., 2014; Wasmer, 2006).

The paper is laid out as follows. The section 'Skills and Other Determinants and Correlates of Poverty and Inequality' reviews research concerning skills and other determinants and correlates of poverty and inequality. The section 'Data and Methods' describes the data, skill and low-income measures used in the paper, and presents the empirical approach. The section 'Results' contains the results, first presenting univariate and bivariate statistics, and then the results of a simple model that aims to test whether the importance of skills remains after controlling for other factors known to be important to low income. The final section concludes and suggests avenues for further research.

\section{Skills and other determinants and correlates of poverty and inequality}

This study is the first to explore the association between a direct measure of adult skills and income poverty (also referred to as low income) using the LISA data. Intuitively, we expect to find an inverse relationship between skills and low income, however, a priori it is not clear how strong these relationships are once other factors are controlled for. We therefore first review evidence on the determinants, or correlates, of poverty in advanced economies and Canada in particular. Then, building on theories and empirical evidence from the literature on adult skills, education and wage earnings we formulate testable hypotheses regarding the expected relation between, firstly, skills and low income and, secondly, other lowincome determinants such as education while controlling for skill level.

Central to our thinking is the idea, expressed in Sen (1999) and empirical papers such as Green and Riddell (1997), that fundamental skills, such as those of literacy, numeracy and problem solving, provide the capability for persons in society to pursue positive outcomes. Unequal distribution of these skills, called 'functionings' by Sen, may lead to unequal outcomes such as low income. Indeed, as noted in Green and Riddell (p. 8), the relationship between skills and household income is important to investigate as household income can be seen to provide a more complete measure of an individual's ability to participate in society compared to other outcomes such as individual labour market earnings. 
'This article is (C) Emerald Group Publishing and permission has been granted for this version to appear here http://dx.doi.org/10.1108/S1049-258520150000023005. Emerald does not grant permission for this article to be further copied/distributed or hosted elsewhere without the express permission from Emerald Group Publishing Limited.'

In this paper, we focus on the relationship between skills and household income for this reason, although, as we discuss below, investigating the causal relationship between skills and household income would be far more problematic that the relationship between skills and earnings.

\section{Micro-correlates}

Individual and family characteristics associated with low-income risk in Canada are very similar to those of other advanced economies. At an individual level, these are characteristics such as an adult's educational attainment, employment status, immigration status, activity limitations (i.e. disability) and belonging to demographic categories such as aboriginal peoples and visible minorities. At the family level, a household's composition involving aspects such as household size, the structure of age and gender demographics and responsibilities (i.e. carers and earners) is also correlated with risk of low income. Canadian low-income profiles are predominantly based on various monetary cut-offs that are compared to a household's income or consumption level (i.e. Collin \& Jensen, 2009; Crossley \& Curtis, 2006; Milligan, 2008; Murphy, Zhang, \& Dionne, 2012; Norris \& Pendakur, 2013; Sarlo, 2013; Shields, Kelly, Park, Prier, \& Fang, 2011). Due to previously lacking information on non-monetary indicators there are not many Canada-wide poverty profiles based on poverty outcomes such as material deprivation (Heisz \& Langevin, 2011).

At risk of poverty are adults with low levels of educational attainment such as high school dropouts or persons with a high school degree only (Collins \& Jensen, 2009; Heisz \& Langevin, 2011). In comparison to persons with a university degree, these persons are about two to four times as likely to be in low income. Relative to other OECD countries, Canada has a larger population share of persons with postsecondary education and especially non-academic post-secondary education (Boothby \& Drewes, 2006). Recent immigrants, refugees and immigrants from visible minorities are also at risk of poverty (Collins \& Jensen, 2009; Heisz \& Langevin, 2011; Murphy et al., 2012). Depending on the measurement approach, recent immigrants are up to twice as likely to have low income than the average Canadian. With an immigration policy focused on attracting skilled workers, low income among recent immigrants in Canada is not strongly associated with an immigrant's education level but more so with their employment status and earnings (Collins \& Jensen, 2009). Persons with a disability are also at an increased risk of poverty (Murphy et al., 2012; Sarlo, 2013). While workers with a limited activity status tend, on average, to have lower earnings, the risk of poverty for disabled persons is more strongly associated with being out of the labour force and dependent on income support from the government 
'This article is (C) Emerald Group Publishing and permission has been granted for this version to appear here http://dx.doi.org/10.1108/S1049-258520150000023005. Emerald does not grant permission for this article to be further copied/distributed or hosted elsewhere without the express permission from Emerald Group Publishing Limited.'

(Collins \& Jensen, 2009). Aboriginal peoples or persons belonging to a visible minority group also have an increased poverty risk (Collin \& Jensen, 2009; Murphy et al., 2012; Shields et al., 2011). In comparison to white Canadians, Canadian-born persons of visible minorities are twice as likely to be in low income and the risk of visible minority immigrants is even somewhat higher (Shields et al., 2011). In comparison to the average Canadian, aboriginal peoples living off reserve are about 1.7 times as likely to be in low income (Murphy et al., 2012).

Families that have fewer workers, more unemployed persons, and more part-time workers are at an increased risk of poverty (Collins \& Jensen, 2009; Crossley \& Curtis, 2006). This includes families with children and especially single parent families (Murphy et al., 2012; Norris \& Pendakur, 2013; Sarlo, 2013). Single parent families have a low-income rate about double that of the average population (Murphy et al., 2012) and a material deprivation risk about double that of couples with children (Heisz \& Langevin, 2011). Employment-related factors such as lower labour participation and higher instability of earnings are key factors underlying this increased poverty risk for lone parents (Collins \& Jensen, 2009; Morissette \& Ostrovsky, 2007). Single working-age persons are also more likely to be found among the working poor (Murphy et al., 2012; Sarlo, 2013). While seniors in general have a much lower than average risk of poverty in Canada (though less so when using a relative low-income line), elderly persons living alone have an above average risk (Collins \& Jensen, 2009; Milligan, 2008).

\section{Information-Processing Skills and the Labour Market}

A key mechanism by which skills influence a person's poverty status is through the labour market. Persons with higher skills are presumably more productive, have higher wages and thus a lower likelihood that their income falls below the low-income threshold. Green and Riddell (2007) pursue the question of how skills affect labour market earnings and find that skills enter a standard earnings determination equation with a positive and significant effect. Skills were also found in that study to reduce the size of the effect attributable to education level, reflecting the important correlation between the skills and education variables. Green and Riddell note that skills and education are codetermined with increases in education leading to higher skills which in turn facilitate access to more education. OECD (2013a, 2013b) also notes that the process through which a person acquires skills is complex, as skill generation interacts with employment and earnings. Indeed, persons acquire skills through the education system, training, at work, and in many other settings such as family and leisure time. 
'This article is (C) Emerald Group Publishing and permission has been granted for this version to appear here http://dx.doi.org/10.1108/S1049-258520150000023005. Emerald does not grant permission for this article to be further copied/distributed or hosted elsewhere without the express permission from Emerald Group Publishing Limited.'

A person's education and skill level are therefore positively related and thus education is an often used proxy for a person's skill level in research focusing on educational and labour market outcomes. For instance, studies assessing the efficiency of labour markets aim to find out whether workers are well matched to their jobs and whether they receive equivalent compensation (i.e. Chiswick \& Miller, 2008; Hartog, 2000). Oftentimes such research uses a workers' educational attainment as a proxy for their skills and required education levels for the job as a proxy for required skill level of the job. The resulting educational 'mismatches' (i.e. workers that are over- or undereducated relative to the requirements of their job) are potentially of concern because they may be symptoms of an inefficient labour market. However, with the availability of direct skill measures such as those from the PIAAC programme studies have shown that educational mismatches can in part be attributed to skills heterogeneity among workers with the same level of educational attainment (Levels, van der Velden, \& Allen, 2014). In other words, education mismatches and skill mismatches are only weakly correlated (i.e. Green \& Mclntosh, 2007). Thus, once controlling for education level, skills have an independent effect on labour market participation, employment and wage earnings (Allen, Levels, van der Velden, 2013; OECD, 2013a, 2013b). This evidence informs the two empirical hypotheses tested in this paper:

Hypothesis 1: Skills have an independent effect on low income. This hypothesis is a logical extension from the finding that, once controlling for education, skills have an independent effect on labour market participation, employment and wage earnings.

Hypothesis 2: The inclusion of skills also influences the effect of education on low income. This hypothesis builds on the evidence from studies explaining wage effects arising from a (seeming) mismatch between a worker's education/ skills and that required by her job (Allen et al., 2013). While this literature shows that education is a relatively weak proxy for skills, it is expected that the generally positive correlation between these two variables results in a smaller individual effect of education once skills are controlled for.

It should be acknowledged that if determining the impact of skills on earnings is complicated, understanding the impact of skills on household income is even more so, as household income depends on the individual earnings of its household members, who would each have different skills which would be correlated in an unknown way (Osberg, 1981). As a result, we do not attempt to interpret our results as causal, rather, we seek to understand the importance of skill in a compositional setting, and ask 
'This article is (c) Emerald Group Publishing and permission has been granted for this version to appear here http://dx.doi.org/10.1108/S1049-258520150000023005. Emerald does not grant permission for this article to be further copied/distributed or hosted elsewhere without the express permission from Emerald Group Publishing Limited.'

whether we observe a tendency towards low skills in the low-income population after controlling for other factors known to increase the risk of low income.

\section{Other Determinants of Poverty and Inequality and the Skills Effect}

In addition to the above-discussed skills-labour supply-earnings mechanism, there are other factors at play that influence the relationship between skills and a household's income. Demographic processes such as family formation may also affect household income. The literature on assortative mating posits that educational homogeneity among spouses, that is, the tendency of persons to marry a spouse with similar educational attainment, contributes to income inequality (Breen \& Andersen, 2012; Breen \& Salazar, 2011; Mare, 1991). If skills also play a role in assortative mating and thus family formation they can, in turn, reinforce individual earnings inequalities at the level of households and their income.

Social protection institutions influence a household's disposable income through the workings of the tax-transfer system. Progressive tax and transfer systems reduce poverty and inequality, in general, and thus also economic outcomes resulting from heterogeneity in skills. As a result, systems with larger and/or more progressive redistribution are more likely to attenuate the earnings effects of skills on a household's disposable income (Heisz \& Murphy, 2014). Moreover, labour market regulations and unionisation may also attenuate the effects of skills on the personal earnings distribution. Cross-national research suggests that differences in the returns to skills (wages) vary more by country than by employment status (OECD, 2013a, 2013b, p. 226). 'In countries with weak labour market protection', Levels et al. (2014, p. 978) 'find stronger direct effects of skills on wages and in these countries a larger proportion of the observed wage effects can be accounted for by skills'. The direct effect of skills on wages is found to be relatively high in Canada (Levels et al., 2014, p. 975; OECD, 2013a, 2013b, p. 229). This evidence further supports the first hypothesis in this paper, namely, that we expect a direct effect of skills on low income.

Finally, recent research regarding the effect of poverty on cognitive function contributes evidence to a long suspected vicious cycle in which poverty reduces a person's cognitive function, thereby reducing a person's capability to escape from poverty (Haushofer \& Fehr, 2014; Mani, Mullainathan, Shafir, \& Zhao, 2013). Other things equal, a person currently experiencing poverty may thus score lower in tests such as PIAAC. Estimating this feedback loop is an important topic for further study, one that is beyond the scope of this paper. 
'This article is (C) Emerald Group Publishing and permission has been granted for this version to appear here http://dx.doi.org/10.1108/S1049-258520150000023005. Emerald does not grant permission for this article to be further copied/distributed or hosted elsewhere without the express permission from Emerald Group Publishing Limited.'

\section{Data and methods}

The dataset used in this research is from the first wave of the LISA. LISA is a longitudinal household survey that collects social and economic data about the Canadian population every two years. The first wave was collected data between November 2011 and June 2012.

The LISA contains two unique features that make it specifically suited for studying the correlation between adult skills and low income. First, LISA includes high-quality micro-data on personal and household income retrieved from annual income tax files provided by the Canada Revenue Agency for the year 2011. This data is collected for each family member aged 15 and over and summed to yield household income. In $16.5 \%$ of cases, individual level income could not be obtained from the income tax files, and in these cases, the LISA data imputes income using a nearest neighbour method. ${ }^{2}$ In total, including children aged 0-14 from whom no income data was captured, LISA contains information on 32,133 respondents living in 11,458 households.

A second unique feature of LISA is that, in that survey, one respondent in each household containing a person between the ages of 16 and 65 (inclusive) was selected to complete the PIAAC assessment. Initiated by the Organization of Cooperation and Development (OECD), PIAAC is designed to assess the skills and competencies of working aged adults across 26 countries, including most countries in the European Union, Canada, Australia and the United States (OECD, 2013a, 2013b). In total, 8,598 LISA respondents completed the PIAAC assessment. ${ }^{3}$

For this study, we focus on results using the subset of LISA respondents who completed a PIAAC assessment, as it is for these respondents alone that we have a complete set of background characteristics, the PIAAC assessment scores, and household income values. Appropriate weights are available and used for this sub-sample. We use the full LISA dataset only for the computation of LIM thresholds (as described below). When we need to distinguish between the full LISA sample and the LISAPIAAC sample, we refer to the former as the LISA sample. The household level response rate to the

\footnotetext{
${ }^{2}$ Our main results are unaffected by whether imputed information is included or excluded.

${ }^{3}$ These 8,598 LISA respondents form a subset of the total 27,285 Canadian PIAAC respondents, the rest of whom were not, by design, included in the LISA project, and for whom there is no longitudinal follow up planned nor household income data collected. For this reason, we are using the LISA data rather than the PIAAC data to conduct this research. Situ (2014) compares results for PIAAC and LISA and finds that these give nearly identical results regarding the skills distributions of Canadians.
} 
'This article is (C) Emerald Group Publishing and permission has been granted for this version to appear here http://dx.doi.org/10.1108/S1049-258520150000023005. Emerald does not grant permission for this article to be further copied/distributed or hosted elsewhere without the express permission from Emerald Group Publishing Limited.'

LISA survey was $72 \%$, and survey weights are adjusted for household level non-response using information on non-responding households from the Canadian Census.

\section{Skill Measures in PIAAC}

The PIAAC direct measure of skills consists of an assessment in three domains: literacy, numeracy and problem solving in technology-rich environments (PS-TRE). The assessment aims to measure the fundamental cognitive skills that are needed to participate in society. Each domain is measured on a scale ranging from 0 to 500. PIAAC divides the scores into different levels to facilitate the interpretation of results. Higher levels correspond to higher proficiency, and each level corresponds to a description of what adults with particular scores can do in concrete terms. ${ }^{4}$

PIAAC defines literacy, numeracy and PS-TRE as follows:

literacy [is defined] as understanding, evaluating, using and engaging with written texts to participate in society, to achieve one's goals, and to develop one's knowledge and potential ... numeracy as the ability to access, use, interpret and communicate mathematical information and ideas, in order to engage in and manage the mathematical demands of a range of situations in adult life ... problem solving in technology-rich environments is defined as using digital technology, communication tools and networks to acquire and evaluate information, communicate with others and perform practical tasks. (OECD, 2012, p. 20)

A framework was established for each of the domains, and these frameworks guided the construction and interpretation of the assessment tasks. The framework for each of the domains considers the dimensions of the context, cognitive strategies, and content. The context refers to the situation in which the skill is used, such as work or personal. The cognitive strategies refer to the mental processes required to apply the skill. The content refers to the material related to the domain. Cognitive strategies and content will vary depending on the domain being assessed. For example, cognitive strategies for literacy skills refer to mental processes related to accessing, identifying, integrating, interpreting, evaluating and reflecting on the content; whereas for PS-TRE, they refer to the mental processes related

\footnotetext{
${ }^{4}$ In this paper, we give only as brief a description of PIAAC scores as is necessary to understand our results. More detail on the PIAAC scores is available at: Statistics Canada, http://www.statcan.gc.ca/pub/89-555x/2013001/t/tbl1.1-eng.htm, accessed 30 October 2014 and OECD (2012).
} 
'This article is (C) Emerald Group Publishing and permission has been granted for this version to appear here http://dx.doi.org/10.1108/S1049-258520150000023005. Emerald does not grant permission for this article to be further copied/distributed or hosted elsewhere without the express permission from Emerald Group Publishing Limited.'

to setting goals, organising and planning tasks, acquiring and evaluating information and using information (OECD, 2012).

Certain limitations in the context of a large-scale assessment also affect the interpretation of the assessment scores. First, difficulties associated with evaluating a person's ability to communicate through written prose or to verbally communicate interpretation of numeracy-related content result in the assessment reflecting mainly the consumption of information as opposed to the communication of information. Second, the assessments were offered in English and French in Canada; as a result, a lack of proficiency in the test language affects the accuracy of the assessment task. Lastly, PS-TRE could only be assessed when the respondent had basic information technology skills and did not opt to complete only a paper-based test rather than the standard computer-based test completed by most respondents. Fig. 1 shows the distribution of LISA respondents across the skill distributions for the three skill types. For literacy, there are five proficiency levels with an additional category 'below Level 1' defined by a particular score-point range.

Figure 1. LISA-PIAAC skills scores distribution

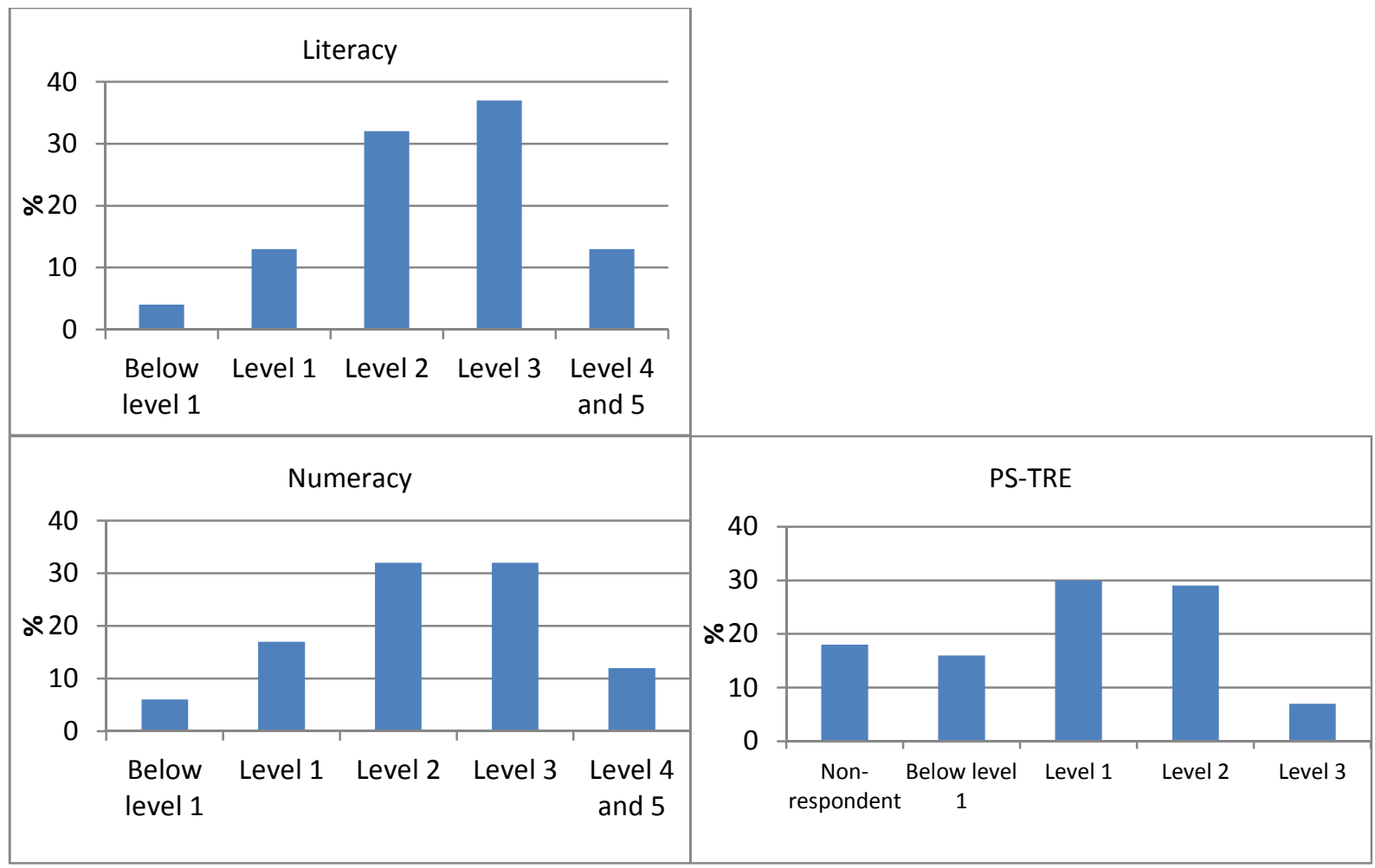

Source: Author's calculations based in Longitudinal and International Study of Adults data 
'This article is (C) Emerald Group Publishing and permission has been granted for this version to appear here http://dx.doi.org/10.1108/S1049-258520150000023005. Emerald does not grant permission for this article to be further copied/distributed or hosted elsewhere without the express permission from Emerald Group Publishing Limited.'

According to the LISA data, $4.3 \%$ of Canadians have a literacy score below Level 1, demonstrating only a basic vocabulary, as well as the ability to read brief texts on familiar topics to locate a single piece of specific information. Canadian's literacy rises to $36.7 \%$ at Level 3. It is common to group Level 4 with Level 5 , and $13.4 \%$ of Canadians achieved this highest level of literacy where 'they can undertake tasks that involve integrating information across multiple dense texts and reasoning by inference' ${ }^{5}$

Numeracy scores were likewise divided into five proficiency levels with the additional category 'below Level 1' also defined. Canadians clustered into the Levels 2 and 3 categories of numeracy with $32.4 \%$ and $32.6 \%$ of Canadians falling into these groups, respectively. Fully $23.5 \%$ of Canadians had levels of numeracy of Level 1 or below Level 1. A score of Level 1 indicates that the respondent has the skills to perform simple mathematical operations involving a single step, such as counting or ordering, while below Level 1 means they can cope with very simple tasks placed in concrete, familiar contexts where the mathematical content is explicit and requires only simple processes.

As indicated above, the PS-TRE could not be assessed if the respondent could or would not participate in the computer-based assessment. The PIAAC sub-sample in LISA has $18.3 \%$ that did not have a PS-TRE assessment for this reason. Presumably, many of these respondents would have had low PS-TRE skills because the main reasons for not participating in the computer-based assessment were related to low information and communication technologies (ICT) skills or literacy skills. According to Statistics Canada (2013), 19\% of PIAAC respondents were not assessed for PS-TRE. Of this group, 10\% were not assessed because they either had no experience with computers, or they failed the test of their basic computer skills. Of the remaining $8 \%$, a total of $6 \%$ opted out of the computer-based assessment in favour of the paper-based version, even though they reported having experience with computers, the remaining $2 \%$ were unable to undertake the assessment for literacy-related reasons such as being unable to speak or read in English or French. ${ }^{6}$

Regarding the LISA-PIAAC sample, 15.6\% scored below Level 1 at which individuals display the requisite ICT abilities for undertaking the test, but in their abilities to solve problems they fall short of Level 1. An estimated $30.8 \%$ of Canadians scored Level 1 , meaning that they can solve problems that have an

\footnotetext{
${ }^{5}$ Statistics Canada, http://www.statcan.gc.ca/pub/89-555-x/2013001/chap1-eng.htm, accessed 30 October 2014. ${ }^{6}$ Statistics Canada, http://www.statcan.gc.ca/pub/89-555-x/2013001/chap1-eng.htm\#n2, accessed 30 October 2014.
} 
'This article is (c) Emerald Group Publishing and permission has been granted for this version to appear here http://dx.doi.org/10.1108/S1049-258520150000023005. Emerald does not grant permission for this article to be further copied/distributed or hosted elsewhere without the express permission from Emerald Group Publishing Limited.'

explicitly stated goal, and that involve a relatively small number of steps to be completed in familiar environment.

The skill scores are reflected in the dataset using a plausible value (PV) methodology. Not all respondents were asked all test questions because of the large volume of content and the limited survey time. PIAAC produced 10 sets of PVs which are multiple imputations to measure each of the skill domains by creating models based on the responses of the subset of test items that a respondent received combined with other background information (e.g. gender, country of birth, education, occupation, employment status, reading practices, etc.) provided by the respondent. These PVs are used to produce group-level estimations of proficiency values in each of the skill domains. We use the methodology demonstrated in Situ (2014) to produce estimates and standard errors with PVs in the LISA-PIAAC data.

The three domains assessed in PIAAC rely on the same 'core' cognitive processes (OECD, 2012). Thus, there is a high degree of correlation between the assessment scores. This correlation is further accentuated through the PV methodology which uses the same background information to produce the scores of each skills domain. In LISAPIAAC data, the correlation coefficient between literacy and numeracy scores is 0.87 . The correlation is 0.82 between literacy and PS-TRE when restricting the sample to those with PS-TRE scores. The correlation between numeracy and PS-TRE is 0.75 . Levels et al. (2014) note that literacy and numeracy skills are highly correlated and thus only use literacy while reserving numeracy for sensitivity tests. OECD (2013a, 2013b, chapter 3) takes a similar approach. Accordingly, while we present some descriptive results for each skill dimension, we focus mainly on literacy skills in our analysis. Use of only numeracy scores or PS-TRE scores would produce similar results. A different approach was used by Green and Riddell (2007) in their study of the 2003 International Adult Literacy Survey where they averaged across the skill scores and used this average in their study. We prefer to use the approach of examining the skill scores separately in LISAPIAAC as it facilitates the calculation of robust standard errors using the PVs generated by the survey for analysis. Furthermore, we tested regression models using each skill score separately and combined. When included separately, each skill score had a statistical significant model coefficient; however, when all skill scores were included, only literacy remained statistically significant. 
'This article is (C) Emerald Group Publishing and permission has been granted for this version to appear here http://dx.doi.org/10.1108/S1049-258520150000023005. Emerald does not grant permission for this article to be further copied/distributed or hosted elsewhere without the express permission from Emerald Group Publishing Limited.'

\section{Measuring Low Income}

An objective of the study is to describe the skills profile of the Canadian Low-income population. Accordingly, we need to classify LISA respondents as in or not in low income. Several considerations need to be raised when doing this.

First, when studying low income, it is preferable to use as complete a definition of income as possible, including government transfers and income taxes. In this study, we use 'after-tax and transfer' income. This includes income from market sources, including earnings, self-employment income and income from investments. It also includes income from government transfers. Government transfer income includes benefits from retirement income programmes such as the Canada and Quebec Pension Plans, the Old Age Security supplement and the General Income Supplement, income from social assistance (or welfare) programmes, income from employment insurance programmes, and income from federal and provincial child benefits. It also includes income from workers compensation benefits and a host of other smaller transfers to persons and families. Finally, it deducts provincial and federal income taxes. Other taxes such as payroll taxes, sales taxes, and property taxes are not excluded from income as they are not collected in this survey.

Second, one would also want to measure income at the level of the spending unit. LISA is well placed to do this as all household members are interviewed. In the event that an interview is not obtained from a particular household member, the survey imputes income for that member. Following the convention used by many analysts, we aggregate income to the household level.

Another consideration is that households with higher income tend to be larger than those with lower income, and there are economies of scale that can be enjoyed by larger families (e.g. they can share the cost of housing). For these reasons, it is a common practise to adjust household incomes to make the incomes of different household sizes comparable. There are a few accepted methods for making this adjustment. In this paper, we adjust household income using the 'square root method'. In this method, household income is divided by an adjustment factor equal to the square root of household size. This adjusted amount is then attributed to all household members and analysis is done at the person level. Thus, for the bulk of our analysis, we use low-income measures based on 'adult equivalent adjusted (AEA) after-tax household income'. 
'This article is (c) Emerald Group Publishing and permission has been granted for this version to appear here http://dx.doi.org/10.1108/S1049-258520150000023005. Emerald does not grant permission for this article to be further copied/distributed or hosted elsewhere without the express permission from Emerald Group Publishing Limited.'

For this paper, individuals are considered to have low income if their AEA-adjusted after-tax income is below a threshold defined as $50 \%$ of the median AEA household after-tax income. This method produces a rate commonly referred to in Canada as the Low-Income Measure After-Tax or LIM-AT.

\section{The Analytical Method}

In this paper, we use univariate and bivariate descriptive statistics, as well as a multivariate model, to analyse skills and low income, not because we wish to articulate all of the influences of household income, but rather because we wish to see if the relationship between low income and skills remains after controlling for other known risk factors associated with low income. The empirical strategy therefore is to compare estimates of $\beta$ in the following equation across multiple models with and without control factors to measure how the relationship with low income changes:

$$
Y_{i}=\alpha+\beta X_{i}+\varepsilon_{i}
$$

Eq. (1) is estimated as a linear probability model of being in low income. $Y$ takes on the value 1 if individual $\mathrm{i}$ is in low income, and 0 otherwise. $\mathrm{X}$ is a vector for dummy variables representing literacy levels or known correlates of poverty or both, depending on the model. Overall, the research uses five models corresponding to different definitions of $X$ (additional models to test the sensitivity of results to different assumptions are presented in the appendix). Depending on the model, $\mathrm{X}$ may include one or more correlates of low income including likely determinants such as educational attainment, immigrant status, the presence of activity limitations and family-type controls. Basic demographic control factors are also used including age, sex and province of residence. The change in the magnitude and significance of the $\beta$ values across the models for estimates associated with literacy skills indicates the change in the incidence of low income across these groups with and without such factors. $\beta$ values can be interpreted as the increase or decrease in the low-income rate associated with that particular $\mathrm{X}$ variable. The models we estimate show correlative rather than causal relationships. A linear probability model is chosen over a logit model to facilitate the comparison of $\beta$ across the different models.

A linear probability model provides a good approximation to logit models when the mean of the dependent variable is not close to zero or one (Moffitt, 1999). Nevertheless, the results were verified using a logit model and similar results were obtained. 
'This article is (C) Emerald Group Publishing and permission has been granted for this version to appear here http://dx.doi.org/10.1108/S1049-258520150000023005. Emerald does not grant permission for this article to be further copied/distributed or hosted elsewhere without the express permission from Emerald Group Publishing Limited.'

The inclusion of an ordinal variable such as literacy poses a challenge because standard regression techniques assume that all explanatory variables are cardinal numbers (Osberg, 2000). This not only implies that there is no straightforward choice to scale literacy scores but also that the chosen scale may affect the sign and magnitude of estimated coefficients of the literacy and other explanatory variables 'in unpredictable or irregular ways' (Cliff, 1996, p. 92). Following Osberg (2000), the results of our lead model (Model 4) were verified using six alternative scaling methods. ${ }^{7}$ The literacy effects vary with the scale used, but the relatively moderate differences do not affect our conclusions.

One concern that is raised from our approach relates to the fact that while income is measured at the household level, skills are measured at the level of the individual. It is likely that the skills of other persons in the household also affect low-income status. Due to the way in which the survey was conducted, skills for only one person in the household are available, so we cannot account for the importance of skills of other persons in the household who would also be contributing to household income. Thus, the results should be thought of as providing information on the composition of the lowincome population, rather than as one that estimates the determinants of low income. It should also be underscored that the after-tax income is composed of earnings, government transfers and taxes. While a strong link could be made between skills and earnings, it would be harder to make a case supporting a causal link between skills and transfers or taxes.

\section{Results}

In this section, we present the main parts of our analyses of skills and low income. In the section 'Low Income and Skills', we describe income distributional differences among skill groups. In the section 'Skills and Other At-Risk Factors', we focus on skill profiles of groups found in other research to be most 'atrisk' of low income. In the section 'Model Results', we present the results of regression models which aim to describe the statistical importance of skills and other 'at-risk' factors in explaining the observed variance in low-income status.

\footnotetext{
${ }^{7}$ The results are provided in the supplementary appendix.
} 
'This article is (C) Emerald Group Publishing and permission has been granted for this version to appear here http://dx.doi.org/10.1108/S1049-258520150000023005. Emerald does not grant permission for this article to be further copied/distributed or hosted elsewhere without the express permission from Emerald Group Publishing Limited.'

\section{Low Income and Skills}

Table 1 presents income distribution statistics from LISAPIAAC, for the full sample and for skill proficiency sub-groups, focussing upon distributional differences among literacy skill groups (results for Numeracy and PS-TRE statistics are available from the authors).

Median household income was $\$ 67,958$ in 2011 for all Canadians. When we calculate medians according to the level of proficiency in literacy each respondent obtained, it shows that skill level and household income are positively related. At $\$ 84,583$, median household income for respondents with literacy proficiency levels in the Levels 4 and 5 category was 33.2\% larger than respondents in the Level 2 proficiency category, and $70.2 \%$ higher than respondents with Level 1 and below. The next line shows median AEA-adjusted income, which, as indicated above, is household income divided by the square root of household size. The levels of income are smaller, but the relative patterns prevail with the high literacy groups having substantially higher incomes than the lower skilled groups.

Table 1. Income distribution by PIAAC score level, literacy

\begin{tabular}{|l|c|c|c|c|c|}
\cline { 2 - 6 } \multicolumn{1}{c|}{} & \multicolumn{5}{c|}{ Literacy score } \\
\hline Medians & $\begin{array}{c}\text { Level 1 and } \\
\text { below }\end{array}$ & Level 2 & Level 3 & $\begin{array}{c}\text { Level 4 and } \\
5\end{array}$ & All \\
\hline Median household income (\$) & 49,696 & 63,520 & 74,568 & 84,583 & 67,958 \\
\hline Median AEA (\$) & 31,512 & 39,625 & 47,073 & 54,369 & 42,576 \\
\hline
\end{tabular}

\begin{tabular}{|l|r|r|r|r|r|}
\hline \multicolumn{7}{|l|}{ Low-income rate } \\
\hline Less than 50\% median (\%) & 29.3 & 16.7 & 11.1 & 8.3 & 15.7 \\
\hline Less than 60\% median (\%) & 37.1 & 23.0 & 15.1 & 11.6 & 21.1 \\
\hline Less than 40\% median (\%) & 20.4 & 11.8 & 8.3 & 6.0 & 11.2 \\
\hline Less than 30\% median (\%) & 11.2 & 6.8 & 5.0 & 3.6 & 6.5 \\
\hline
\end{tabular}

Source: Author's calculations based in Longitudinal and International Study of Adults data

The lower panel of Table 1 presents low-income rates for each skill proficiency group. The first row shows the low-income rate based on the $50 \%$ of median AEA income threshold we use throughout this study. The lowincome rate for the Levels 4 and 5 group was, at $8.3 \%$, half the level seen in the skill 
'This article is (C) Emerald Group Publishing and permission has been granted for this version to appear here http://dx.doi.org/10.1108/S1049-258520150000023005. Emerald does not grant permission for this article to be further copied/distributed or hosted elsewhere without the express permission from Emerald Group Publishing Limited.'

proficiency 2 group and nearly one-quarter the level seen in skill group 1 or below, reflecting a clear association between skill level and the incidence of low income. The respondents with both low skill level and low income can be viewed, in the words of Green and Riddell (p. 13) as suffering from a 'double poverty' and at risk of being severely disadvantaged in terms of their ability to function in society. Estimates suggest that in 2011, about $5 \%$ of Canadians aged 16 to 65 had both low income and a low skill level. ${ }^{8}$

It could be that this ranking of low-income rates depends upon the particular threshold used, and that a different threshold would provide a different ranking. The remaining three rows show alternative lowincome rates based on thresholds computed at $60 \%, 40 \%$ and $30 \%$ of low income. The rankings of low income across skill groups are stable (increasing with decreases in skill proficiency) across the alternative indicators indicating that the results would be the same for a wide range of low-income thresholds.

\section{Skills and Other At-Risk Factors}

The broad research on low income in Canada has emphasised certain 'atrisk' groups. These are groups that have much higher incidences of low income and persistent low income than other groups. Groups that have been identified as being at high risk of low income include recent immigrants, people in loneparent families, aboriginal persons, unattached nonelderly persons, and people with activity limitations. Recent immigrants are defined as having arrived in Canada in the 10 years preceding the survey. The group 'unattached non-elderly persons' refers specifically to unattached persons aged 45-64. This group has a high low-income rate, which is thought to be associated with higher rates of disability and nonemployment. The age group stops at 64 since at age 65 persons become eligible for different retirement security programmes that often lift these persons out of low income (Murphy et al., 2012).

Table 2 presents the distribution of skill levels across these poverty risk groups. In each of these cases, at-risk groups have a lower skill profile than do all persons. For example, $17 \%$ of all persons had a literacy score of Level 1 or below. This compares to $30 \%$ of recent immigrants, $23 \%$ of persons in loneparent families, $26 \%$ of aboriginal persons, $27 \%$ of unattached non-elderly persons and $23 \%$ of people with activity limitations.

\footnotetext{
${ }^{8}$ From Fig. 2, 17\% of Canadians had a literacy proficiency level of 1 and below, while from Table 1, 29.3\% of those in that group had low incomes; $0.17 \times 0.293=0.049$.
} 
'This article is (C) Emerald Group Publishing and permission has been granted for this version to appear here http://dx.doi.org/10.1108/S1049-258520150000023005. Emerald does not grant permission for this article to be further copied/distributed or hosted elsewhere without the express permission from Emerald Group Publishing Limited.'

Table 2. Literacy proficiencies for groups at high risk of low income

\begin{tabular}{|l|r|r|r|r|}
\cline { 2 - 4 } \multicolumn{1}{c|}{} & \multicolumn{3}{|c|}{ Literacy score (\% distribution) } \\
\hline All persons & $\begin{array}{c}\text { Level } 1 \\
\text { and } \\
\text { below }\end{array}$ & Level 2 & $\begin{array}{c}\text { Level } 4 \\
\text { and } 5\end{array}$ \\
\hline & 17 & 32 & 37 & 13 \\
\hline Recent immigrants (immigrated after 2002) & 30 & 34 & 28 \\
\hline People in lone-parent family & 23 & 36 & 32 \\
\hline Aboriginal people & 26 & 35 & 33 \\
\hline Unattached non-elderly persons & 27 & 35 & 7 \\
\hline People with Activity Limitations & 23 & 33 & 32 \\
\hline
\end{tabular}

Source: Author's calculations based in Longitudinal and International Study of Adults data

The literature review presented earlier described the determination of low income as being, in part, associated with the finding and holding of employment. Certainly, in the working aged population, employment and wages determine low-income status, as the social safety net for working aged persons is not typically sufficient to raise recipients over the lowincome threshold (Echenberg, 2012). In addition to the at-risk factors presented above, education level is known to be an important determinant of wages (Morissette, Picot, \& Lu, 2013), and in turn it would be an important determinant of low-income status among the working aged population. Moreover, skills would also be highly correlated with educational attainment, as the generation of skills is an important output of the educational system, and the presence of basic skills such as literacy could be important pre-requisites to entering higher education levels.

Table 3 presents the distribution of literacy across four education groups, revealing that important differences in literacy are present across education groups. Comparing respondents with at most a high school degree with those who have a university degree or higher, $28 \%$ of the latter group scored a Level 4 or higher on the literacy assessment compared to $8 \%$ among the former. Likewise, university graduates were much less likely to score level one or below on the literacy assessment than were respondents with lower education. However, educational attainment was not perfectly correlated with literacy levels, as significant shares of respondents with lower education also achieved higher skill 
'This article is (C) Emerald Group Publishing and permission has been granted for this version to appear here http://dx.doi.org/10.1108/S1049-258520150000023005. Emerald does not grant permission for this article to be further copied/distributed or hosted elsewhere without the express permission from Emerald Group Publishing Limited.'

proficiency levels. This adds support to the proposal that skills may have an effect on low income that is independent of educational attainment, a question we turn to in the section 'Model Results'.

Table 3. Literacy proficiencies by education group

\begin{tabular}{|c|c|c|c|c|}
\hline & \multicolumn{4}{|c|}{ Literacy score (\% distribution) } \\
\hline Highest education level & $\begin{array}{c}\text { Level } 1 \\
\text { and } \\
\text { below }\end{array}$ & $\begin{array}{l}\text { Level } \\
2\end{array}$ & $\begin{array}{l}\text { Level } \\
3\end{array}$ & $\begin{array}{c}\text { Level } \\
4 \text { and } \\
5\end{array}$ \\
\hline No certificate, diploma or degree, or non-response & 44 & 36 & 18 & 2 \\
\hline High school diploma or equivalent & 17 & 39 & 37 & 8 \\
\hline College, CEGEP or other non-university certificate or diploma & 13 & 35 & 41 & 11 \\
\hline $\begin{array}{l}\text { University certificate or diploma (including below Bachelor level, } \\
\text { Bachelor's level, and above Bachelor's level) }\end{array}$ & 6 & 21 & 44 & 28 \\
\hline
\end{tabular}

Source: Author's calculations based in Longitudinal and International Study of Adults data

\section{Model Results}

In this section, we present the results of a regression model designed to test whether the relationship between skills and low income persists once other characteristics common to low-income populations are controlled for. The empirical strategy is to estimate a model with a low-income dummy variable as the dependent variable and skill dummy variables as independent variables. Then other regressions are run while at-risk factors are added in sequentially to see how these change the skills coefficient. The resulting estimated values for skills can be thought of as a first and crude exploration of the effect that skills may have on low income. As indicated earlier, further research is needed to unravel the size and direction of hypothesised causal pathways between skills and low income.

Table 4 shows descriptive statistics for the variables included in the regression models. Statistics show the share of 16- to 65-year olds within various respondent groups, as well as the group low-income rate. Statistics for literacy are the same as those shown in Fig. 1 and Table 1, respectively, and show that the low-income rate is higher for lower skilled persons. As expected, the rate of low income is also higher for persons with less education. For example, the rate of low income among persons with a high school degree was at $18.7 \%$ just more than twice the rate of those with a university degree $(9.2 \%)$. 
'This article is (C) Emerald Group Publishing and permission has been granted for this version to appear here http://dx.doi.org/10.1108/S1049-258520150000023005. Emerald does not grant permission for this article to be further copied/distributed or hosted elsewhere without the express permission from Emerald Group Publishing Limited.'

Table 4. Descriptive statistics

\begin{tabular}{|c|c|c|}
\hline Characteristic & $\%$ of population & \% below LIM \\
\hline \multicolumn{3}{|l|}{ Literacy levels } \\
\hline Level 1 and below & 17 & 26.4 \\
\hline Level 2 & 32 & 16.7 \\
\hline Level 3 & 37 & 11.1 \\
\hline Level 4 and 5 & 13 & 8.3 \\
\hline \multicolumn{3}{|l|}{ Highest education level } \\
\hline No certificate, diploma or degree & 16 & 26.5 \\
\hline High school diploma or equivalent & 26 & 18.7 \\
\hline College, CEGEP or other non-university certificate or diploma & 31 & 13.3 \\
\hline University certificate or diploma & 27 & 9.2 \\
\hline Immigrant & 100 & \\
\hline Yes - immigrated after 2002 & 6 & 24.8 \\
\hline Yes - immigrated in 2002 or before & 14 & 16.1 \\
\hline No & 80 & 14.9 \\
\hline \multicolumn{3}{|l|}{ Activity limitation } \\
\hline Has an activity limitation & 19 & 26.5 \\
\hline Does not have an activity limitation & 81 & 13.1 \\
\hline \multicolumn{3}{|l|}{ Family type } \\
\hline Couple family & 68 & 8.7 \\
\hline Lone parent & 10 & 30.7 \\
\hline Persons not in a census family & 22 & 30.2 \\
\hline \multicolumn{3}{|l|}{ Aboriginal people } \\
\hline Yes & 3 & 15.5 \\
\hline No & 97 & 22.7 \\
\hline \multicolumn{3}{|l|}{ Unattached non-elderly persons } \\
\hline Yes & 9 & 33.5 \\
\hline No & 91 & 13.9 \\
\hline \multicolumn{3}{|l|}{ Sex } \\
\hline Male & 50 & 15.2 \\
\hline Female & 50 & 16.3 \\
\hline \multicolumn{3}{|l|}{ Age } \\
\hline $16-19$ & 7 & 14.9 \\
\hline $20-24$ & 10 & 25.6 \\
\hline $25-34$ & 20 & 14.3 \\
\hline $35-44$ & 20 & 14.0 \\
\hline $45-54$ & 23 & 14.5 \\
\hline $55-65$ & 20 & 15.6 \\
\hline \multicolumn{3}{|l|}{ Province } \\
\hline Atlantic (N.L., P.E.I., N.S., N.B.) & 7 & 19.0 \\
\hline Que. & 23 & 18.0 \\
\hline Ont. & 39 & 16.6 \\
\hline Prairies (Man., Sask., Alta.) & 18 & 10.2 \\
\hline B.C. & 13 & 14.8 \\
\hline
\end{tabular}


'This article is (C) Emerald Group Publishing and permission has been granted for this version to appear here http://dx.doi.org/10.1108/S1049-258520150000023005. Emerald does not grant permission for this article to be further copied/distributed or hosted elsewhere without the express permission from Emerald Group Publishing Limited.'

Low income was higher among immigrants than the Canadian born, and was higher the more recently the person immigrated. For immigrants who arrived in Canada in the 10 years preceding the interview, the rate of low income was $24.8 \%$, while the rate for these who immigrated earlier was, at $16.1 \%$ only slightly above the rate observed for the Canadian born (14.9\%).

In total $19 \%$ of respondents indicated having an activity limitation, and the incidence of low income among those with an activity limitation was, at $26.5 \%$, twice that of those without a limitation. ${ }^{9}$ Activity limitation refers just to the LISAPIAAC respondent and not to other members of the household. Thus, it does not control for the fact that there could be other persons in the household with an activity limitation.

For the purposes of controlling for differences in family type, we use statistics Canada's Census Family concept in the regression analysis. The census family refers to a married couple (with or without children), a common-law couple (with or without children) or a lone-parent family. Remaining unattached persons are defined as 'persons not in a census family'. Multiple census families and persons not in a census family can live together to form a household, so, while low income is defined at the household level, families are defined at the more traditional 'nuclear family' level. Low income for persons in couple families (married or unmarried) was at $8.7 \%$, less than one third the low-income rate of persons in lone-parent families (30.7\%) or persons not in census families (30.2\%).

Finally, Table 4 also shows low-income rates by sex, age and province. Low-income rates were slightly higher for women, higher for persons aged 2024 and lower in western provinces of Canada.

Table 5 presents the results of the regression exercise described in the section 'Data and Methods', Eq. (1). The model is a linear regression model, so the coefficients represent the increased or decreased probability of being in low income relative to the omitted category. Column 1 shows the results including only the literacy variables. Literacy Levels 4 and 5 combined represent the omitted category, so the results indicate that holding sex, age and province constant, the low-income rate for persons scoring Level 1 and below is 21.3 percentage points higher than the rate for respondents scoring in the Levels 4 or 5 . Level 2 is 8.5 percentage points higher and Level 3 is 2.8 points higher. These results are

\footnotetext{
${ }^{9}$ Having an activity limitation is identified in the LISA survey through the combination of two questions: (1) Do you have any long-standing illnesses or long-standing health problems that have lasted or are expected to last for 6 months or more? (2) To what extent have you been limited because of this health problem in everyday activities? Would you say that you have been severely limited, limited but not severely or not limited at all?
} 
'This article is (C) Emerald Group Publishing and permission has been granted for this version to appear here http://dx.doi.org/10.1108/S1049-258520150000023005. Emerald does not grant permission for this article to be further copied/distributed or hosted elsewhere without the express permission from Emerald Group Publishing Limited.'

similar to those shown in Table 1 and differ from those results due to the effect of controls on sex, age and province included in this model.

The second column adds controls for educational attainment. The coefficient of educational attainment is significant in this model, with respondents with a high school degree having a 6.4 percentage point higher low-income rate than university degree holders (the reference category). The addition of educational attainment to the model also reduces the size of the coefficients on the skill variables. For example, the coefficient for proficiency Level 1 and below drops from 0.213 to 0.162 , or nearly onequarter. This would be expected considering the relationship between education and literacy demonstrated in the previous section. It also lines up well with results from Green and Riddell (2007) which showed a weakening of the importance of years of education when skills are added to an earnings regression.

The third column adds immigrant status while the fourth includes activity limitation and family controls. These variables enter the model with significance and in the expected direction. Moreover, they enter the model without changing the coefficients for the education variables very much, but they do reduce the size of the coefficients on skills. After controlling for these other background characteristics, skills remain significant predictors of low income, but their magnitude is reduced substantially. After all controls are entered into the model, the disadvantage associated with literacy Level 1 and below drops to 12.1 points, still a large effect, but much smaller that the effect without these other controls. ${ }^{10}$

The fifth column includes all variables except the literacy dummy variables. This is done to examine the effect of literacy on the other variables, rather than the effect of the other variables on literacy as has been done up to now. Coefficients for education and immigration status are larger than in Model 4 where literacy was included, while coefficients for activity limitations and family types are unchanged. Adding literacy to the model results in the disadvantage associated with having (at most) a high school degree to fall from 8.6 percentage points (Model 5) to 6.2 points (Model 4), a reduction of 38\%. Meanwhile, it reduces the disadvantage associated with being a recent immigrant (in the last 10 years) from 15.0 percentage points to 12.2 percentage points (down 19\%).

\footnotetext{
${ }^{10} \mathrm{An}$ additional model was estimated that added in controls for the respondent being an aboriginal person and the respondent being an unattached non-elderly person. The addition of these extra variables did not affect the estimates presented in model 4 , so we did not pursue this model further.
} 
'This article is (C) Emerald Group Publishing and permission has been granted for this version to appear here http://dx.doi.org/10.1108/S1049-258520150000023005. Emerald does not grant permission for this article to be further copied/distributed or hosted elsewhere without the express permission from Emerald Group Publishing Limited.'

Table 5. Linear regression models

\begin{tabular}{|c|c|c|c|c|c|}
\hline & Model 1: & Model 2: & Model 3: & Model 4: & Model 5: \\
\hline & \multicolumn{5}{|c|}{$\mathrm{DV}=$ Low income } \\
\hline \multicolumn{6}{|l|}{ Literacy level } \\
\hline \multirow[t]{2}{*}{ Level 1 and below } & $0.213^{* * *}$ & $0.162 * * *$ & $0.149 * * *$ & $0.121^{* * *}$ & \\
\hline & $(0.022)$ & $(0.024)$ & $(0.024)$ & $(0.024)$ & \\
\hline \multirow[t]{2}{*}{ Level 2} & $0.085^{* * *}$ & $0.058 * * *$ & $0.050 * * *$ & $0.042 * *$ & \\
\hline & $(0.018)$ & $(0.019)$ & (0.019) & $(0.020)$ & \\
\hline \multirow[t]{2}{*}{ Level 3} & $0.028^{*}$ & 0.015 & 0.011 & 0.010 & \\
\hline & $(0.016)$ & $(0.016)$ & $(0.016)$ & $(0.017)$ & \\
\hline \multicolumn{6}{|l|}{ Level 4 and 5 (Ref Cat) } \\
\hline \multicolumn{6}{|l|}{ Education } \\
\hline \multirow[t]{2}{*}{ No certificate, diploma or degree } & & $0.124 * * *$ & $0.134 * * *$ & $0.122 * * *$ & $0.177^{* * *}$ \\
\hline & & $(0.020)$ & $(0.021)$ & $(0.020)$ & $(0.018)$ \\
\hline \multirow[t]{2}{*}{ High school diploma or equivalent } & & $0.064 * * *$ & $0.072 * * *$ & $0.062 * * *$ & $0.086 * * *$ \\
\hline & & $(0.015)$ & $(0.015)$ & $(0.014)$ & $(0.013)$ \\
\hline \multicolumn{6}{|l|}{ College, CEGEP or other non-university } \\
\hline \multirow[t]{2}{*}{ certificate or diploma } & & 0.020 & $0.029 * *$ & $0.023^{*}$ & $0.039 * * *$ \\
\hline & & $(0.013)$ & $(0.013)$ & $(0.012)$ & $(0.012)$ \\
\hline \multicolumn{6}{|c|}{ University certificate or diploma (Ref cat) } \\
\hline \multicolumn{6}{|l|}{ Immigrant } \\
\hline \multirow[t]{2}{*}{ Yes - immigrated after 2002} & & & $0.090 * * *$ & $0.122^{* * *}$ & $0.150 * * *$ \\
\hline & & & $(0.025)$ & $(0.025)$ & $(0.025)$ \\
\hline \multirow[t]{2}{*}{ Yes - immigrated in $\mathbf{2 0 0 2}$ or before } & & & 0.005 & 0.025 & $0.044 * * *$ \\
\hline & & & $(0.017)$ & $(0.016)$ & $(0.016)$ \\
\hline \multicolumn{6}{|l|}{ No (Ref Cat) } \\
\hline \multicolumn{6}{|l|}{ Activity limitation } \\
\hline \multirow[t]{2}{*}{ Has an activity limitation } & & & & $0.106 * * *$ & $0.108^{* * *}$ \\
\hline & & & & $(0.015)$ & $(0.015)$ \\
\hline \multicolumn{6}{|c|}{ Does not have an activity limitation (Ref Cat) } \\
\hline \multicolumn{6}{|c|}{ Family type } \\
\hline \multirow[t]{2}{*}{ Lone parent } & & & & $0.183 * * *$ & $0.190 * * *$ \\
\hline & & & & $(0.022)$ & $(0.022)$ \\
\hline \multirow[t]{2}{*}{ Persons not in a census family } & & & & $0.202 * * *$ & $0.208 * * *$ \\
\hline & & & & $(0.015)$ & $(0.015)$ \\
\hline \multicolumn{6}{|l|}{ Couple family (Ref Cat) } \\
\hline \multirow[t]{2}{*}{ Intercept } & $0.096 * * *$ & $0.074 * * *$ & $0.076 * * *$ & 0.000 & 0.024 \\
\hline & $(0.021)$ & $(0.021)$ & $(0.021)$ & $(0.022)$ & $(0.018)$ \\
\hline Age, Sex and Province controls & $\mathrm{Y}$ & $\mathrm{Y}$ & $\mathrm{Y}$ & $\mathrm{Y}$ & $\mathrm{Y}$ \\
\hline $\mathrm{N}$ & 8,598 & 8,598 & 8,598 & 8,598 & 8,598 \\
\hline R-squared & 0.051 & 0.061 & 0.064 & 0.144 & 0.134 \\
\hline
\end{tabular}

$* * *, * * *$ indicate statistical significance at the $1 \%, 5 \%$ and $10 \%$ levels

Source: Author's calculations based in Longitudinal and International Study of Adults data 
Fig. 2. Raw and Adjusted Literacy Skills Effects on Low Income.

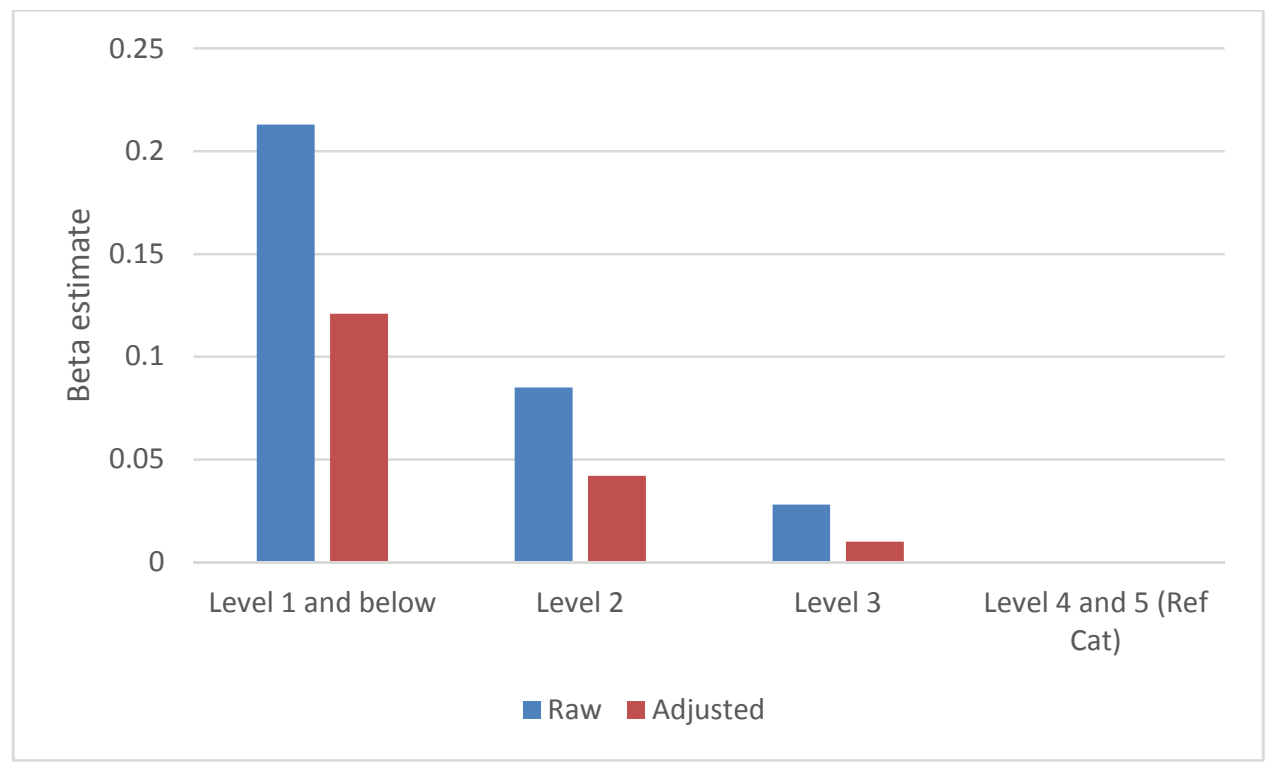

Source: Author's calculations based in Longitudinal and International Study of Adults data.

Fig. 2 summarises the predicted average literacy effects from the regression results in Table 5. Raw literacy effects (from Model 1) are large, especially for persons with literacy level 1 and below. Adjusted effects (from Model 4) are muted, but still large in size for literacy proficiency levels of 2 and below.

\section{Conclusion}

In this paper, we make use of a unique dataset that provides information on household income and skills of Canadians to examine the relationship between skills and low income. Given the well-known importance of skills in employment and earnings generation, we expect to find evidence that skills would also have an important role to play in the determination of family income and low income. What remained to be answered was whether the inclusion of skills into the discourse adds anything extra after the effects of other risk factors such as education, immigrant status, activity limitations and others are taken into account.

Our results suggest that skills do matter even after these other controls are added in, however, the 'independent' effect of skills is muted compared to the 'raw' effect due to correlations between skills and other risk factors. On the other hand, the inclusion of skills also reduces the importance of educational attainment and immigrant status, indicating that part of the higher incidence of low income among at-risk groups is associated with lower skills in these groups. 
'This article is (C) Emerald Group Publishing and permission has been granted for this version to appear here http://dx.doi.org/10.1108/S1049-258520150000023005. Emerald does not grant permission for this article to be further copied/distributed or hosted elsewhere without the express permission from Emerald Group Publishing Limited.'

These results could be interpreted in light of Amartya Sen's capabilities framework for understanding well-being. In this framework, persons need a minimum level of basic resources and important personal characteristics that Sen called 'functionings' to be capable of pursuing their basic goals. Lack of a basic functioning, like literacy, would inhibit persons from achieving their goals, resulting in lower well-being. At the same time, family income can be seen as an indicator of overall well-being, a reflection of how well persons are able to enjoy and participate in life fully, and low income can be seen to reflect a situation where barriers to participation in society can be most binding. Thus, the observed statistical relationship between low skills and low income would fit the expectations of Sen's framework.

The results suggest that a better understanding of the role of skills on low income could have implications for the design of programmes to reduce poverty. For example, the finding that the low-skill proficiency group has a higher incidence of low income could inform the design of education and skill policy. Likewise, the result that there is an association between low skills, immigrant status and low income could inform the development of immigration programmes.

Further research could take advantage of the panel nature of the data to examine whether initial skills (measured in the first wave of the data) have effects on the transition out of low income in the second. Alternatively retrospective income data, also available with LISA, could be used to study the skills and income question in a dynamic framework. It is possible that those with higher skill levels are disproportionately part of the transient poor while the lower skill levels are more likely to be among the chronic poor. Finally, other dependent variables such as the depth of low income or receipt of social transfers could also be examined in future work. 
'This article is (C) Emerald Group Publishing and permission has been granted for this version to appear here http://dx.doi.org/10.1108/S1049-258520150000023005. Emerald does not grant permission for this article to be further copied/distributed or hosted elsewhere without the express permission from Emerald Group Publishing Limited.'

\section{Bibliography}

Allen, J., Levels, M., \& van der Velden, R. (2013). Skill mismatch and skill use in developed countries: Evidence from the PIAAC study, ROA-RM-2013/17, Maastricht University.

Boothby, D., \& Drewes, T. (2006). Postsecondary education in Canada: Returns to university, college and trades education. Canadian Public Policy/Analyse de Politiques, 32(1), 1-21.

Breen, R., \& Andersen, S. H. (2012). Educational assortative mating and income inequality in Denmark. Demography, 49(3), 867-887.

Breen, R., \& Salazar, L. (2011). Educational assortative mating and earnings inequality in the United States. American Journal of Sociology, 117(3), 808-843.

Chiswick, B., \& Miller, P. (2008). Why is the payoff to schooling smaller for immigrants? Labour Economics, 15(6), 1317-1340.

Cliff, N. (1996). Dominance statistics: Ordinal analyses to answer ordinal questions. Psychological Bulletin, 114(3), 494-509.

Collin, C., \& Jensen, H. (2009). A statistical profile of poverty in Canada. (PRB 09-17E). Parliamentary Information and Research Service of the Library of Parliament.

Crossley, T., \& Curtis, L. (2006). Child poverty in Canada. Review of Income and Wealth, 52, 237260.

Echenberg, H. (2012). The poverty prism: The causes of poverty. Social Affairs Division, Parliamentary Information and Research Service, Library of Parliament.

Green, D., \& Riddell, W. C. (2007). The generation of literacy and its impact on earnings for native born Canadians. Statistics Canada Catalogue no. 89-552-MIE No.18.

Green, D. A., \& Riddell, W. C. (1997). Qualifying for unemployment insurance: An empirical analysis. The Economic Journal, 107, 67-84.

Green, F., \& McIntosh, S. (2007). Is there a genuine under-utilization of skills amongst the overqualified? Applied Economics, 39(4), 427-439.

Gyarmati, D., Leckie, N., Dowie, M., Palameta, B., Hui, T. S.-w., \& He' bert, S. (2014). UPSKILL: A credible test of workplace literacy and essential skills training. CLSRN Working Paper no. 143, University of British Columbia.

Hamilton, D., \& Torraco, R. (2013). Integrative review of the literature on adults with limited education and skills and the implications for human resource development. Human Resource Development Review, 12(3), 308-328. 
'This article is (C) Emerald Group Publishing and permission has been granted for this version to appear here http://dx.doi.org/10.1108/S1049-258520150000023005. Emerald does not grant permission for this article to be further copied/distributed or hosted elsewhere without the express permission from Emerald Group Publishing Limited.'

Hartog, J. (2000). Over-education and earnings: Where are we, where should we go? Economics of Education Review, 19(2), 131-147.

Haushofer, J., \& Fehr, E. (2014). On the psychology of poverty. Science, 344(6186), 862-867.

Heisz, A., \& Langevin, M. (2011). Material deprivation in household panel surveys: International evidence and lessons for canada. In G. Fre' chet, D. Gauvreau, \& J. Poirier (Eds.), Statistics sociales, pauvrete ' et exclusion sociale: Hommage a 'paul bernard (pp. 269-277). Montre' al: Les Presses de I'Universite' de Montre' al.

Heisz, A., \& Murphy, B. (2014). The role of taxes and transfers in reducing income inequality, draft.

Levels, M., van der Velden, R., \& Allen, J. (2014). Educational mismatches and skills: New empirical tests of old hypotheses. Oxford Economic Papers, 66(4), 959982.

Mani, A., Mullainathan, S., Shafir, E., \& Zhao, J. (2013). Poverty impedes cognitive function. Science, 341(6149), 976980.

Mare, R. (1991). Five decades of educational assortative mating. American Sociological Review, 56(1), 1532.

Milligan, K. (2008). The evolution of elderly poverty in canada. Canadian Public Policy/ Analyse De Politiques, 34, 7994.

Moffitt, R. A. (1999). New developments in econometric methods for labor market analysis. In O. Ashenfelter \& D. Card (Eds.), Handbook of labor economics (Vol. 3A). Amsterdam: North-Holland Elsevier.

Morissette, R., \& Ostrovsky, Y. (2007). Income instability of lone parents, singles and twoparent families in Canada, 1984 to 2004. (Catalogue no. 11F0019MIE No. 297). Ottawa: Statistics Canada.

Morissette, R., Picot, W. G., \& Lu, Y. (2013). The evolution of Canadian wages over the last three decades. Statistics Canada.

Murphy, B., Zhang, X., \& Dionne, C. (2012). Low income in Canada: A multi-line and multiindex perspective. (Catalogue no. 75F0002M No. 001). Ottawa: Statistics Canada.

Norris, S., \& Pendakur, K. (2013). Imputing rent in consumption measures, with an application to consumption poverty in canada, 19972009. Canadian Journal of Economics/ Revue Canadienne d'E 'conomique, 46(4), 15371570.

OECD. (2012). Literacy, numeracy and problem solving in technology-rich environments: Framework for the OECD Survey of Adult Skills. Paris: OECD Publishing. 
'This article is (C) Emerald Group Publishing and permission has been granted for this version to appear here http://dx.doi.org/10.1108/S1049-258520150000023005. Emerald does not grant permission for this article to be further copied/distributed or hosted elsewhere without the express permission from Emerald Group Publishing Limited.'

OECD. (2013a). Skills outlook: First results from the OECD Survey of Adult Skills (Vol. 1). Paris: OECD Publishing.

OECD. (2013b). Technical report of the OECD survey of adult skills (PIAAC). Paris: OECD Publishing.

Osberg, L. (1981). Economic inequality in Canada. Toronto: Butterwork \& Co. (Canada) Ltd.

Osberg, L. (2000). Schooling, literacy and individual earnings. Catalogue no. 89-552-MPE, no. 7. Ottawa: Statistics Canada.

Sarlo, C. (2013). Poverty: Where do we draw the line? Vancouver: Fraser Institute.

Sen, A. (1999). Commodities and capabilities. OUP Catalogue.

Shields, J., Kelly, P., Park, S., Prier, N., \& Fang, T. (2011). Profiling immigrant poverty in Canada: A 2006 census statistical portrait. Canada Review of Social Policy/Revue canadienne de politique sociale, 65, 92111.

Situ, J. (2014). Using PIAAC direct measures of skills in LISA. Statistics Canada, Draft.

Statistics Canada. (2013). Skills in Canada: First results from the Program for International Assessment of Adult Competencies (PIAAC), Statistics Canada Cat. No. 89-555-X.

Wasmer, E. (2006). General versus specific skills in labor markets with search frictions and firing costs. The American Economic Review, 96(3), 811831.

\section{Acknowledgement}

The authors would like to thank Adriene Harding. 
'This article is (C) Emerald Group Publishing and permission has been granted for this version to appear here http://dx.doi.org/10.1108/S1049-258520150000023005. Emerald does not grant permission for this article to be further copied/distributed or hosted elsewhere without the express permission from Emerald Group Publishing Limited.'

Appendix: Sensitivity analysis of alternate scaling of literacy scores

Osberg (2000) makes the methodological point that research using direct measures of skill attainment should test for the robustness of statistical results by examining a variety of monotonic transformations. We conduct such tests on our lead model (Model 4) using six monotonic transformations and conclude that the observations in our results remain valid. That is, skills do matter even after the effects of other risk facts are controlled. However, depending on the transformation, the effect varies. Model 4 showed that after all controls are entered into the model, the disadvantage associated with literacy Level 1 and below drops to 12.1 points (from 21.3) compared to the model without controls. Across the six transformations explored, this effect varies between 9.3 points and 14.2 points.

The six transformations explored are similar to those used by Osberg (2000) and consist of: (1) a log transformation (Model A); (2) successively higher power transformation (Model BD, where the model contains the literacy score raised to the power 1, 3, 5, respectively) and (3) truncation of low and high scores (Model E truncates scores below Level 1 to a score of zero and scores in Level 5 to a score of 500; and Model F truncates scores below Level 1 to a score of 175 and scores in Level 5 to a score of 326). The models are explored using only one set of PVs, as opposed to all 10 sets, to reduce the computational demands.

Table A1 presents the results of the regression exercise for the six models containing different transformations of the literacy scores. The first column is Model 1 from the main analysis that shows the results of including only the literacy variable. The second column is Model 4 from the main analysis that shows the results of including all the control variables. The sensitivity models are variations of Model 4 where the literacy variable is replaced with the transformed literacy variable.

To compare the differences in the literacy effect across the models, predicted probabilities of being in low income are calculated for each model while holding the control variables at the sample mean. These predicted probabilities are used to calculate the mean probability of being in low income for each of the literacy groups. These results, for each of the sensitivity models, are displayed in Fig. A1.

The impact of the transformations is similar to those observed by Osberg (2000). Osberg found that successively higher powers emphasise the importance of differences at the top end of the literacy distribution, while a logarithmic transformation compresses the influence of differentials at the top end (thus, indirectly emphasising the bottom end). In Table 1 in the main paper, the low-income rate is 
'This article is () Emerald Group Publishing and permission has been granted for this version to appear here http://dx.doi.org/10.1108/S1049-258520150000023005. Emerald does not grant permission for this article to be further copied/distributed or hosted elsewhere without the express permission from Emerald Group Publishing Limited.'

observed to change the most at the low end of the literacy distribution. Thus, a model that emphasises the high end of the distribution, where the low-income rate does not change as much, would show lower effects of literacy on low income when compared to a logarithmic transformation. This is observed in Fig. A1 where Model D (a power-5 transformation) has less difference in the predicted lowincome rate across the literacy groups compared to Model A (a logarithmic transformation).

Transformations involving different truncations of the tails of the literacy distribution explore the sensitivity of the results to variations that could occur at the tails as a result of the PV imputation methodology. A low number of test items exist at the tails because most people are in the mid-range of the distribution; thus, variations in the tails may not be a result of differences in responses to test items, but instead the imputation methodology. Fig. A1 shows the results from the two truncations are in the same range as the other sensitivity models.

In conclusion, transformations of the literacy score will alter the size of the effect of literacy on low income; however, across all the transformations explored, we continue to find that skills do matter even after the effects of other risk factors are controlled (Fig. A2). 
'This article is (C) Emerald Group Publishing and permission has been granted for this version to appear here http://dx.doi.org/10.1108/S1049-258520150000023005. Emerald does not grant permission for this article to be further copied/distributed or hosted elsewhere without the express permission from Emerald Group Publishing Limited.'

Table A. Linear regression models sensitivity tests, for literacy using plausible value set 1

\begin{tabular}{|c|c|c|c|c|}
\hline & Model 1: & Model 4: & $\begin{array}{l}\text { Model A } \\
\text { (log lit): }\end{array}$ & $\begin{array}{c}\text { Model B } \\
\text { (lit): }\end{array}$ \\
\hline \multicolumn{5}{|c|}{ DV=Low income } \\
\hline \multicolumn{5}{|l|}{ Literacy level } \\
\hline \multirow[t]{2}{*}{ Level 1 and below } & $0.220 * * *$ & $0.129 * * *$ & & \\
\hline & $(0.018)$ & $(0.020)$ & & \\
\hline \multirow[t]{2}{*}{ Level 2} & $0.097 * * *$ & $0.051^{* * *}$ & & \\
\hline & $(0.014)$ & $(0.015)$ & & \\
\hline \multirow[t]{2}{*}{ Level 3} & $0.038 * * *$ & 0.019 & & \\
\hline & $(0.013)$ & $(0.014)$ & & \\
\hline \multicolumn{5}{|l|}{ Level 4 and 5 (Ref Cat) } \\
\hline \multirow[t]{2}{*}{ Log (literacy score) } & & & $-0.232 * * *$ & \\
\hline & & & $(0.032)$ & \\
\hline \multirow[t]{2}{*}{ Literacy score $\left(\times 10^{-3}\right)$} & & & & $-0.917 * * *$ \\
\hline & & & & $(0.123)$ \\
\hline \multicolumn{5}{|l|}{ Education } \\
\hline \multirow[t]{2}{*}{ No certificate, diploma or degree } & & $0.120 * * *$ & $0.105^{* * *}$ & $0.107^{* * *}$ \\
\hline & & $(0.020)$ & $(0.020)$ & $(0.020)$ \\
\hline \multirow[t]{2}{*}{ High school diploma or equivalent } & & $0.060 * * *$ & $0.051 * * *$ & $0.049 * * *$ \\
\hline & & $(0.014)$ & $(0.014)$ & $(0.014)$ \\
\hline \multicolumn{5}{|c|}{ College, CEGEP or other non-university certificate or } \\
\hline \multirow[t]{2}{*}{ diploma } & & $0.021^{*}$ & 0.015 & 0.013 \\
\hline & & $(0.012)$ & $(0.012)$ & $(0.012)$ \\
\hline \multicolumn{5}{|c|}{ University certificate or diploma (Ref cat) } \\
\hline \multicolumn{5}{|c|}{ Immigrant } \\
\hline \multirow[t]{2}{*}{ Yes - immigrated after 2002} & & $0.121 * * *$ & $0.111^{* * *}$ & $0.113^{* * *}$ \\
\hline & & $(0.025)$ & $(0.025)$ & $(0.025)$ \\
\hline \multirow[t]{2}{*}{ Yes - immigrated in 2002 or before } & & 0.024 & 0.018 & 0.019 \\
\hline & & $(0.016)$ & $(0.016)$ & $(0.016)$ \\
\hline \multicolumn{5}{|l|}{ No (Ref Cat) } \\
\hline \multicolumn{5}{|l|}{ Activity limitation } \\
\hline \multirow[t]{2}{*}{ Has an activity limitation } & & $0.107 * * *$ & $0.105^{* * *}$ & $0.106 * * *$ \\
\hline & & $(0.015)$ & $(0.015)$ & $(0.015)$ \\
\hline \multicolumn{5}{|c|}{ Does not have an activity limitation (Ref Cat) } \\
\hline \multicolumn{5}{|c|}{ Family type } \\
\hline \multirow[t]{2}{*}{ Lone parent } & & $0.185^{* * *}$ & $0.184 * * *$ & $0.184 * * *$ \\
\hline & & $(0.022)$ & $(0.022)$ & $(0.022)$ \\
\hline \multirow[t]{2}{*}{ Persons not in a census family } & & $0.202 * * *$ & $0.201 * * *$ & $0.202 * * *$ \\
\hline & & $(0.015)$ & $(0.015)$ & $(0.015)$ \\
\hline \multicolumn{5}{|l|}{ Couple family (Ref Cat) } \\
\hline Intercept & $0.086 * * *$ & -0.007 & $1.340 * * *$ & $0.294 * * *$ \\
\hline & $(0.019)$ & $(0.020)$ & $(0.182)$ & $(0.040)$ \\
\hline Age, Sex and Province controls & $\mathrm{Y}$ & $\mathrm{Y}$ & $\mathrm{Y}$ & $\mathrm{Y}$ \\
\hline $\mathrm{N}$ & 8,598 & 8,598 & 8,598 & 8,598 \\
\hline R-squared & 0.050 & 0.144 & 0.147 & 0.146 \\
\hline
\end{tabular}

$* * *, * *, *$ indicate statistical significance at the $1 \%, 5 \%$ and $10 \%$ levels

Source: Author's calculations based in Longitudinal and International Study of Adults data 
'This article is (C) Emerald Group Publishing and permission has been granted for this version to appear here http://dx.doi.org/10.1108/S1049-258520150000023005. Emerald does not grant permission for this article to be further copied/distributed or hosted elsewhere without the express permission from Emerald Group Publishing Limited.'

Table A. Linear regression models sensitivity tests, for literacy using plausible value set 1 (continued)

\begin{tabular}{|c|c|c|c|c|}
\hline & $\begin{array}{l}\text { Model C } \\
\left.\text { (lit }{ }^{3}\right):\end{array}$ & $\begin{array}{l}\text { Model D } \\
\left.\text { (lit }{ }^{5}\right):\end{array}$ & $\begin{array}{c}\text { Model E } \\
(<176 \rightarrow 0 \text {, } \\
>326 \rightarrow \\
500):\end{array}$ & $\begin{array}{c}\text { Model F } \\
(<176 \rightarrow \\
175, \\
>=326 \rightarrow \\
326):\end{array}$ \\
\hline$(\text { Literacy score) })^{3}\left(\times 10^{-8}\right)$ & $\begin{array}{c}-0.351 * * * \\
(0.050)\end{array}$ & $D V=$ LoV & me & \\
\hline$(\text { Literacy score })^{5}\left(\times 10^{-13}\right)$ & & $\begin{array}{c}-0.194 * * * \\
(0.032)\end{array}$ & & \\
\hline Literacy score: truncate $<176 \rightarrow 0,>326 \rightarrow 500\left(\times 10^{-3}\right)$ & & & $\begin{array}{c}-0.355^{* * *} \\
(0.055)\end{array}$ & \\
\hline Literacy score: truncate $<176 \rightarrow 175,>=326 \rightarrow 326\left(\times 10^{-3}\right)$ & & & & $\begin{array}{c}-1.068 * * * \\
(0.141)\end{array}$ \\
\hline \multicolumn{5}{|l|}{ Education } \\
\hline No certificate, diploma or degree & $\begin{array}{l}0.121 * * * \\
(0.020)\end{array}$ & $\begin{array}{c}0.136 * * * \\
(0.019)\end{array}$ & $\begin{array}{c}0.125^{* * *} \\
(0.019)\end{array}$ & $\begin{array}{c}0.109 * * * \\
(0.020)\end{array}$ \\
\hline High school diploma or equivalent & $\begin{array}{c}0.053 * * * \\
(0.014)\end{array}$ & $\begin{array}{c}0.060 * * * \\
(0.014)\end{array}$ & $\begin{array}{c}0.056^{* * *} \\
(0.014)\end{array}$ & $\begin{array}{c}0.051^{* * *} \\
(0.014)\end{array}$ \\
\hline $\begin{array}{l}\text { College, CEGEP or other non-university certificate or } \\
\text { diploma }\end{array}$ & $\begin{array}{c}0.015 \\
(0.012)\end{array}$ & $\begin{array}{c}0.018 \\
(0.012)\end{array}$ & $\begin{array}{c}0.018 \\
(0.012)\end{array}$ & $\begin{array}{c}0.015 \\
(0.012)\end{array}$ \\
\hline \multicolumn{5}{|l|}{ University certificate or diploma (Ref cat) } \\
\hline \multicolumn{5}{|l|}{ Immigrant } \\
\hline Yes - immigrated after 2002 & $\begin{array}{c}0.121 * * * \\
(0.025)\end{array}$ & $\begin{array}{c}0.129 * * * \\
(0.025)\end{array}$ & $\begin{array}{c}0.122 * * * \\
(0.025)\end{array}$ & $\begin{array}{c}0.113 * * * \\
(0.025)\end{array}$ \\
\hline Yes - immigrated in 2002 or before & $\begin{array}{c}0.025 \\
(0.016)\end{array}$ & $\begin{array}{l}0.031^{*} \\
(0.016)\end{array}$ & $\begin{array}{c}0.026 \\
(0.016)\end{array}$ & $\begin{array}{c}0.021 \\
(0.016)\end{array}$ \\
\hline \multicolumn{5}{|l|}{ No (Ref Cat) } \\
\hline \multicolumn{5}{|l|}{ Activity limitation } \\
\hline Has an activity limitation & $\begin{array}{c}0.108 * * * \\
(0.015)\end{array}$ & $\begin{array}{c}0.109 * * * \\
(0.015)\end{array}$ & $\begin{array}{c}0.108^{* * *} \\
(0.015)\end{array}$ & $\begin{array}{c}0.107 * * * \\
(0.015)\end{array}$ \\
\hline \multicolumn{5}{|l|}{ Does not have an activity limitation (Ref Cat) } \\
\hline \multicolumn{5}{|l|}{ Family type } \\
\hline Lone parent & $\begin{array}{c}0.185 * * * \\
(0.022)\end{array}$ & $\begin{array}{c}0.186 * * * \\
(0.022)\end{array}$ & $\begin{array}{c}0.187^{* * *} \\
(0.022)\end{array}$ & $\begin{array}{c}0.184 * * * \\
(0.022)\end{array}$ \\
\hline Persons not in a census family & $\begin{array}{c}0.204 * * * \\
(0.015)\end{array}$ & $\begin{array}{c}0.205^{* * *} \\
(0.015)\end{array}$ & $\begin{array}{c}0.204 * * * \\
(0.015)\end{array}$ & $\begin{array}{c}0.202 * * * \\
(0.015)\end{array}$ \\
\hline \multicolumn{5}{|l|}{ Couple family (Ref Cat) } \\
\hline Intercept & $\begin{array}{c}0.118^{* * *} \\
(0.022)\end{array}$ & $\begin{array}{c}0.075^{* * *} \\
(0.020)\end{array}$ & $\begin{array}{c}0.142 * * * \\
(0.026)\end{array}$ & $\begin{array}{c}0.331 * * * \\
(0.044)\end{array}$ \\
\hline Age, Sex and Province controls & $\mathrm{Y}$ & $\mathrm{Y}$ & $\mathrm{Y}$ & $\mathrm{Y}$ \\
\hline $\mathrm{N}$ & 8,598 & 8,598 & 8,598 & 8,598 \\
\hline R-squared & 0.142 & 0.140 & 0.142 & 0.146 \\
\hline
\end{tabular}

$* * *, * *, *$ indicate statistical significance at the $1 \%, 5 \%$ and $10 \%$ levels

Source: Author's calculations based in Longitudinal and International Study of Adults data 
'This article is (C) Emerald Group Publishing and permission has been granted for this version to appear here http://dx.doi.org/10.1108/S1049-258520150000023005. Emerald does not grant permission for this article to be further copied/distributed or hosted elsewhere without the express permission from Emerald Group Publishing Limited.'

\section{Figure A1: Literacy skills effect on low income}

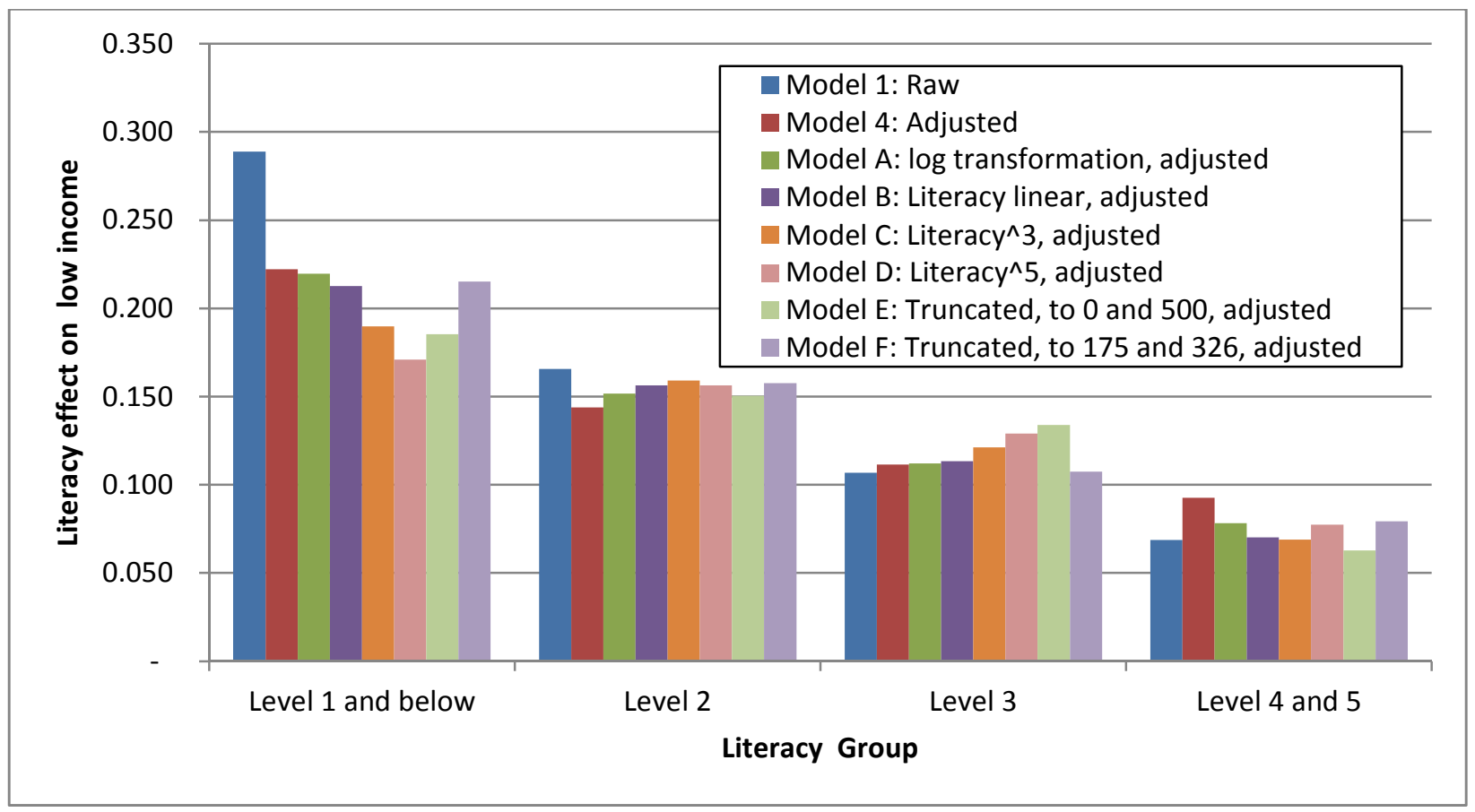

Figure A2: Literacy skills effects on low income, relative to category 4 and 5

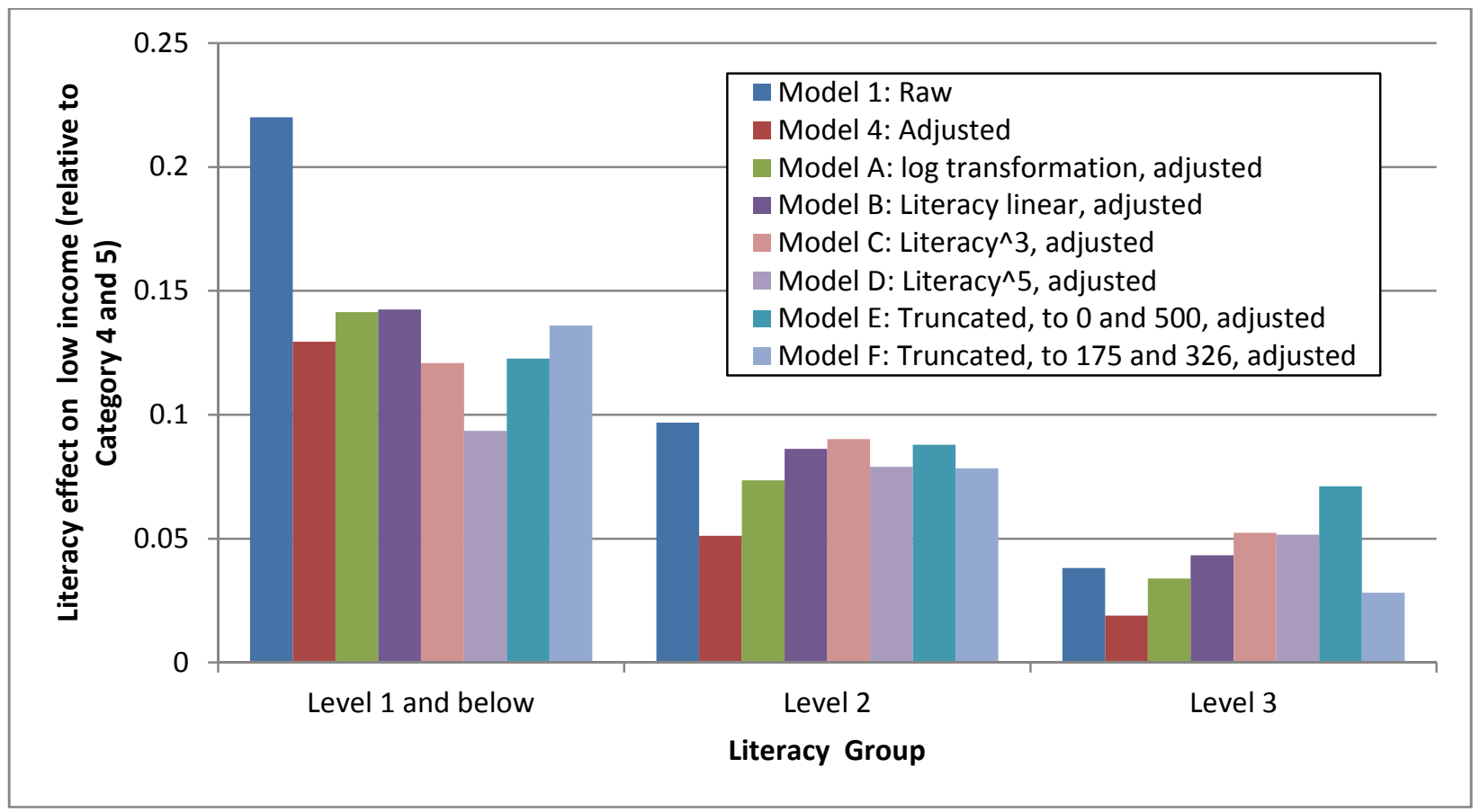

